Portland State University

PDXScholar

\title{
A Cultural History of Black Musicians in Renaissance Europe, 1500-1700
}

Jamar Taylor

Portland State University

Follow this and additional works at: https://pdxscholar.library.pdx.edu/honorstheses

Part of the African History Commons, and the European History Commons Let us know how access to this document benefits you.

\section{Recommended Citation}

Taylor, Jamar, "A Cultural History of Black Musicians in Renaissance Europe, 1500-1700" (2020). University Honors Theses. Paper 890.

https://doi.org/10.15760/honors.911

This Thesis is brought to you for free and open access. It has been accepted for inclusion in University Honors Theses by an authorized administrator of PDXScholar. Please contact us if we can make this document more accessible: pdxscholar@pdx.edu. 
This research project concerning Black Africans in Renaissance Europe is predicated on including Africans into a global history they have largely been excluded from, even though there is ample evidence that proves their cultural influence, in this case, with music. Culture is inextricably linked to the politics of the time. European societies were highly hierarchical, so nothing was approved without the blessing of the elites. In almost every strata of the social hierarchy, music is an important component, from military exhibitions to court and formal events to informal social gatherings. In some European societies, musicians were employed as government officials. By studying early modern art such as paintings and statues, we get a sense of the presence of Africans in Europe. When studied alongside African artwork in the same time period, commonalities and continuities present themselves when making connections between the two continents. This implies that there was a give and take of politics and culture between them. By viewing Africans as active participants in the exchange of bodies, ideas and culture, we can begin to understand the complexities and nuances that brought people of European and African origin together in the fifteenth and sixteenth centuries. 
A Cultural History of Black Musicians in Renaissance Europe, 1500-1700

by

Jamar Taylor

A thesis in partial fulfillment of the requirements for the degree of

\section{BACHELOR OF SCIENCE WITH HONORS}

in

HISTORY

Portland State University

2020 


\section{Contents}

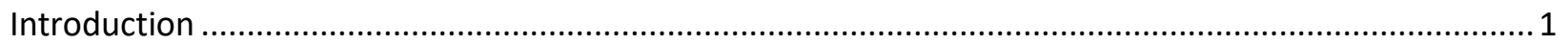

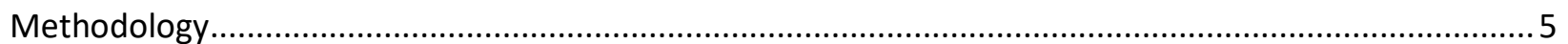

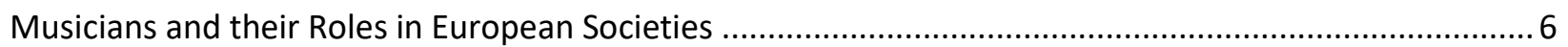

Livelihood: Black Africans in European Societies ...................................................................................... 12

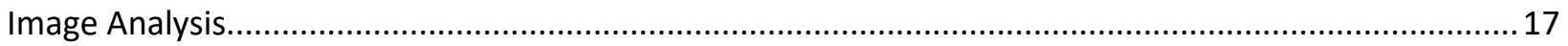

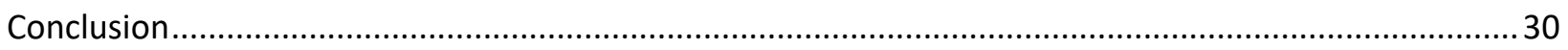

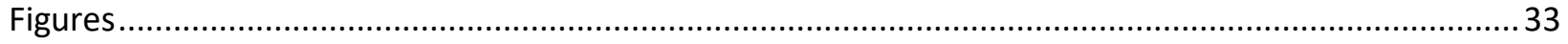





\section{Acknowledgments}

This research project would not exist had it not been for the University's Honors College staff, Robert E. McNair Program, and Portland State University's history department. A special thanks goes out to Dr. Tappan for her expertise in African history and her input as my second reader. And last but certainly not least, I give a special shoutout to Dr. Ott, my thesis advisor. Without his extensive knowledge in Medieval history, and his diligent critique and feedback, this research would not be possible or as fruitful as it has been. Thank you! 


\section{Introduction}

Many historians speak about the African presence in Renaissance Europe from a musical standpoint. Notable scholars, including Kate Lowe, Annemarie Jordan, Aurelia Martin-Casares, Henry Louis Gates Jr, A.C de C.M. Saunders, and many more, have highlighted black musicians in their writings. The book Black Africans in Renaissance Europe is comprised of a collection of essays which analyze Black Africans in various European societies performing different tasks to make a living. A.C de C.M. Saunders discusses the ways in which black Africans lived and contributed to Spain socially, culturally and economically in his historical analysis Social History of Black Slaves and Freedmen in Portugal, 1441-1555. Imtiaz Habib studies the early modern period's parish, obituary, and economic records to draw conclusions about the life and death of black Africans in England in his book Black Lives in the English Archives, 1500-1677: Imprints of the Invisible. ${ }^{1}$ The information from these sources, among others, provides a sense of the black African presence in early modern European countries. These texts argue that black Africans were active community members in their respective societies.

From paintings to secondary and primary sources, there is evidence that suggests subSaharan Africans in Europe were often associated with music, among other social roles. Elmer Kolfin, in his essay, "When Africans Became Black: Dürer, Rubens and the Changing Image of Africans in Northern Europe," describes how skin color became the signifier for black Africans as they were being represented in Renaissance engravings. Kolfin notes that artistic depictions

\footnotetext{
${ }^{1}$ T.F. Earle and K Lowe, eds., Black Africans in Renaissance Europe (Cambridge: Cambridge University Press, 2010); A. C. de C. M, Saunders. A Social History of Black Slaves and Freedmen in Portugal, 1441-1555 (Cambridge: Cambridge University Press, 1982); Imtiaz H. Habib, Black Lives in the English Archives, 1500-1677: Imprints of the Invisible (Aldershot, England; Burlington, VT: Ashgate, 2008).
} 
of black Africans relied on phenotypical features such as fuller lips, larger foreheads and different hair texture compared to Europeans to differentiate their subjects in the early sixteenth century. ${ }^{2}$ Renowned artist Albrecht Dürer (1471-1528) depicted the differences between whites and blacks as he rendered his African subjects in profile view to capture their distinct flat noses and thick mouths. ${ }^{3}$ By 1620 , artists such as Peter Paul Rubens (1577-1640) and Lucas Vorsterman (1595-1675), who were influenced by Dürer, took on the task to render Africans as black. What can be gleaned from the perspective of the aforementioned artists is a sense of eroticism associated with the African presence. Some historians have been quick to note the prejudice displayed in the imagery through eroticism and stereotyping. ${ }^{4}$ In the paintings analyzed in this paper, there are suggestions and allusions to Africans being eroticized in the way they are depicted. But what is implicit, and equally as important to note, is the livelihood of such people in the context of their time. ${ }^{5}$ The examination of the paintings selected for investigation gives us an idea of what the artists may have been attempting to represent in their depictions of African musicians. Some of the examined paintings here marginalize Africans, along with contemporary literature that speaks of them disparagingly.

\footnotetext{
2 Elmer Kolfin, "When Africans Became Black: Durer, Rubens and the Changing Image of Africans in Northern Europe," Print Quarterly, vol. 34, no. 4 (2017): 379-392.

${ }^{3}$ Kolfin, 380.

${ }^{4}$ Kate Lowe, "The Stereotyping of Black Africans in Renaissance Europe," in Black Africans in Renaissance Europe, 17-47.

${ }^{5}$ Onyeka Nubia, England's Other Countrymen: Black Tudor Society (London: Zed Books, 2019), 5. Nubia encourages us to view the past in "pre-colonial" terms as this helps us understand early modern history on its own account as opposed to "post-colonialism." He argues that "post-colonial" perspectives are inadequate because "...Africa had not fallen under European colonial rule and England at the beginning of the early modern period was not a major colonial or imperial power."
} 
Some of the paintings are demeaning and depicts them as slaves. And as we know, bondage is abhorrent in all of its forms, even when it resembles pawnship. ${ }^{6}$

Yet premodern slavery sometimes led to manumission, something completely different to the inherited, chattel slavery we are familiar with in plantation societies. Also, we see freed black slaves ascend in social mobility. ${ }^{7}$ Peter Erickson notes the relative rights and freedoms black Africans experienced throughout early modern Europe when compared to the West Africans taken to the Americas. ${ }^{8}$ Additionally, we should not assume that every African brought to Europe in this time period was held in bondage. ${ }^{9}$ We should therefore consider how the world back then operated on its own terms and see that Africans inhabited Europe under many circumstances. Among the continents that border the Atlantic Ocean, the world was interconnected; people, ideas, politics, commerce and culture were moving around intercontinentally. ${ }^{10}$ Additionally, race, as we know it today, was not the top signifier for

\footnotetext{
${ }^{6}$ Randy J. Sparks, "Gold Coast Merchant Families, Pawning, and the Eighteenth-Century British Slave Trade," The William and Mary Quarterly, vol. 70, no. 2, (2013): 317-340. www.jstor.org/stable/10.5309/willmaryquar.70.2.0317. Sparks remarks on the complex trading system Africans used when engaging with outside traders. Pawns, usually the relatives of African slave traders, were held as collateral. Although he is talking about pawnship as it was used in the 1700s, he does mention that this practice had been common not only in the Gold Coast, but also in Benin.

${ }^{7}$ Accessed online at: https://www.metmuseum.org/art/collection/search/437869. Displayed at this museum is the portrait of Juan de Pareja painted by Diego Velazquez (1650). In this portrait, Pareja is depicted in a confident and noble fashion. He represents an enslaved person that was liberated by his master in 1654. After he was released from bondage, he became an independent painter himself.

${ }^{8}$ Peter Erickson, 2. "Representations of blacks and blackness in the Renaissance," Criticism, vol. 35, no. 4, (1993), 499+. Gale Academic OneFile, https://link-gale com.proxy.lib.pdx.edu/apps/doc/A14690907/AONE?u=s1185784\&sid=AONE\&xid=8cd191fb. Erickson states, "As compared with black Africans in America, blacks in Europe were relatively small in number, relatively well treated in the domestic and entertainment roles to which they were confined, and regulated by color lines that were relatively less strictly fixed or codified." Erickson rightfully notes that the binary line between positive and negative narratives of blacks may be too simplistic of an observation, and I believe more scholarship should focus more on all aspects, drawing from the different versions of competing historical narratives.

${ }^{9}$ Linda M. Heywood, "Slavery and its Transformation in the Kingdom of Kongo: 1491-1800," The Journal of African History, vol. 50, no. 1 (2009): 1-22 at p. 5. Heywood notes that King Afonso (1509-1543) of Kongo sent his kin to Lisbon along with slaves to pay for the upkeep of his family members. Africans were not powerless in this trade. ${ }^{10}$ Heywood, 4. Heywood discusses how King Afonso exchanged letters with King Joao III expressing his discontent for Europeans illegally trading slaves. She notes, "Afonso's language leaves no doubt that Kongo had a group of
} 
discrimination, as ethnic and religious reasons often surpassed it. ${ }^{11}$ Our understanding of race

hardly applies to this time period, so we should consider the concept of the "exotic other."

Although this term has its limitations, and the separate words tend to ambiguity, Peter Erickson

suggests we should identify black Africans as such as this offers more insight to early modern

Western European philosophy. ${ }^{12}$ In some places, there was a relative toleration for differences.

From the paintings and the primary sources of black musicians that others have decrypted,

another, more nuanced narrative can be constructed of Africans in Renaissance Europe, one

that emphasizes their humanity over their labor production. By observing these paintings from

the perspective of an interconnected world, we can view this history from a different lens

where multiculturalism coexists in a hierarchical, yet communal society. This paper attempts to

insert sub-Saharan Africa and Africans into an international history where different political

systems, economic practices and cultures all have influenced one another, consequently forging

connections and continuities between them. ${ }^{13}$ Culture and politics often intertwine, so, the

freeborn commoners." African rulers had standards and procedures they expected foreign traders to follow. Europeans were dependent on Africans for trade in the interior of the continent. This is significant because it shows that Africans had their own political, economic and social systems in place long before European intervention and that the traders had to follow the rules and regulations that were set in place, at least in the early stages of the trans-Atlantic slave trade.

${ }^{11}$ Geraldine Heng, The Invention of Race in the European Middle Ages (Cambridge: Cambridge University Press, 2018), 27. In this book, Heng offers a definition of race that is not solely characterized by skin color, but more along the lines of different religious and cultural practices that date back to at least the late middle ages. She says, "My understanding, thus, is that race is a structural relationship for the articulation and management of human differences, rather than a substantive content." Implicit in this statement is that "otherness" is constructed by powers and institutions in a given society.

12 Erickson, "Representations of blacks and blackness in the Renaissance," 1-2.

${ }^{13}$ Kate Lowe, 19. Lowe speculates that "It is likely that the bunching of a proportion of skilled black Africans in certain occupations in Europe is as much a reflection of the fact that these skills were valued in African society and had already been acquired there as a reflection that they were considered and labelled as suitable or acceptable skills for black Africans in Europe." Although history told from the West African perspective about early modern Europe is lacking, early modern African artwork gives us insight into the skills and practices they were accustomed to. This will be further explored in the "Image Analysis" section of the paper. 
focal point here is the significant role music and black musicians played in European military events, courts and formal events, and informal social gatherings.

\section{Methodology}

In order to understand the significance that art plays in constructing a narrative of the past, we must consider where and when such masterpieces were painted. For this thesis, I have assembled an image database of twenty-two Renaissance paintings that portray black Africans as musicians, collected from museums and their websites, as well as Artstor. These paintings and sculptures come from many European countries, including Italy, England, Spain, Portugal, the Netherlands, Belgium and more. The European artworks were then juxtaposed with contemporary art from West Africa between the sixteenth and eighteenth centuries. The African artists have not been identified, but many of the European painters were renowned and their names still bear significance today. Albrecht Dürer, Peter Paul Rubens, Giulio Romano and Harmenszoon van Rijn Rembrandt all depicted black Africans in their works of art. Their paintings fall into three distinct thematic categories: biblical, religious, and phantasmal; formal and court settings; and military functions. In each one of these categories, black musicians are integral to the composition. This begs the question: are the depictions of black Africans in Renaissance paintings representative of their lot in their respective societies? If so, then we can ask what kinds of impacts they had in cultural terms. In what ways did representations of black musicians reflect cultural values and European stereotypes of West Africans? Coupling Renaissance European art with primary documents presents the possibility that these 
depictions were visual representations of actual events in cosmopolitan societies, or a compilation of several moments composed into one piece of artwork. ${ }^{14}$ And when comparing early modern African and European art, it appears that there were social, political and cultural exchanges between the peoples of the two continents.

\section{Musicians and their Roles in European Societies}

To further explore the context of black African musicians in paintings, a look at how their society treated them is necessary to understand how widespread their influence was on their communities. Many recent studies of early modern musicians and musical performances have begun to broaden our understanding of this wider social context. Fiona Kisby calls for greater discourse between urban historians and musicologists in this area, and stresses the importance of music in urban settings as deserving deeper study. In her book, Music and Musicians in Renaissance Cities and Towns, Kisby argues that "It has been demonstrated that music was not at the periphery of the pre-industrial townscape but rather was a central and significant aspect of the urban experience." 15 Therefore, music was not just a hobby or pastime, rather it was an important aspect of many Europeans' way of life politically, socially, and culturally. For example, in Tess Knighton's text, “Instruments, Instrumental Music and Instrumentalists: Tradition and Transitions," she remarks that, "[Musical] ensembles were

\footnotetext{
${ }^{14}$ Accessed online at: https://estherschreuder.wordpress.com/2020/01/25/from-the-black-is-beautiful-cataloguerembrandts-two-drummers/. Esther Schreuder notes that, "Some of these were compositional studies for paintings or etchings, others he used to record individual ideas or observations for possible incorporation in later works."

${ }^{15}$ Fiona Kisby, Music and Musicians in Renaissance Cities and Towns (Cambridge: Cambridge University Press, 2001), 6.
} 
emblematic of the princely status: trumpets and drums heralded the royal or noble presence in public, notably in the open spaces of street or square, battlefield or joust." ${ }^{16}$ This perspective strengthens the significance of black musicians and centrality to courtly life, as the paintings often depict them playing trumpets and drums.

From Gretchen Peters' essay, "Civic Subsidy and Musicians in Southern France During the Fourteenth and Fifteenth Centuries: A Comparison of Montpellier, Toulouse and Avignon," we get a sense of how integrated musicians were into their respective societies by looking at archival records of city payrolls, account books, and contracts, among other sources. ${ }^{17}$ It is evident that civic musicians were tied to society politically, socially and religiously, even during fluctuations in the economy and population size. ${ }^{18}$ Civic musicians often had careers lasting longer than twenty years and earned an annual salary. And sometimes these positions were passed down to family members for generations. ${ }^{19}$ Peters remarks, “...when a minstrel's annual wage was $7 \mathrm{li}$, the city council offered its notary $100 \mathrm{li}$, its treasurer $60 \mathrm{li}$, and its squires $24 \mathrm{li}$ each. The minstrels did, however, earn more than the individuals who were employed by the city council to repair the roads." ${ }^{20}$ Although not the highest paying city profession, musicians did receive livery and tips. And when compared to other city workers, they were not at the bottom of the economic totem pole. These wages and experiences were common to musicians in all three cities in question, and their musical duties ranged from military and court purposes

\footnotetext{
${ }^{16}$ Tess Knighton, "Instruments, Instrumental Music and Instrumentalists: Traditions and Transitions," in Companion to Music in the Age of the Catholic Monarchs, ed. Tess Knighton (Leiden: Brill, 2017), 110.

${ }^{17}$ Gretchen Peters, "Civic Subsidy and Musicians in Southern France During the Fourteenth and Fifteenth Centuries: A Comparison of Montpellier, Toulouse and Avignon," in Music and Musicians in Renaissance Cities and Towns, ed. Kisby, 57-69.

18 Peters, 65.

19 Peters, 67.

${ }^{20}$ Peters, 64.
} 
to entertainment. Peters also notes that in many European cities, foreigners were often sought after for their musical talents. France was different, in that "the members of the city council preferred to employ native musicians to represent themselves and their city in celebrations and only exceptionally employed foreigners, perhaps when the demands of a new instrument made this necessary." ${ }^{21}$ If France was relatively insular when it came to its musical performers, other European countries desired outsiders to perform musical acts. As Knighton discusses the significance of black musicians in the Iberian world, she states, "The tradition of court musicians of different ethnic origins was firmly consolidated in Spain by the time of the Sixth Duke of Medina Sidonia, Juan Alonso de Guzman." ${ }^{22}$ This is interesting because it gives more credence to the possibility that black Africans were included in European court music and performance because of their foreignness.

Although Peters makes no mention of black Africans as performers in southern France, she does note that, "...Montpellier subsidized a mixed ensemble of reeds, trumpets and drums. Such combinations had been widespread in the urban centres of Europe in the twelfth and thirteenth centuries, largely as a result of Middle Eastern influence." ${ }^{23}$ In fact, European emperors adopted the custom of using black musicians in their retinue from Arabs in the Middle Ages. ${ }^{24}$ This is relevant because Middle Eastern traders and Moorish rulers had been engaged in the trans-Saharan slave trade since the early Middle Ages, often using enslaved

\footnotetext{
${ }^{21}$ Peters, 62.

22 Knighton, 117.

${ }^{23}$ Peters, 61.

${ }^{24}$ Accessed online at: https://estherschreuder.wordpress.com/2020/01/25/from-the-black-is-beautiful-cataloguerembrandts-two-drummers/. Esther Schreuder notes that, "During the twelfth century the German Hohenstaufen adopted the use of black musicians from Arabs: The Liber ad honorem Augusti (1195-1197), for example, shows black trumpeters in the retinue of the emperor Henry VI (1165-1197) in Sicily." Apparently, this tradition held for several centuries as black drummers and trumpeters were held in high regard.
} 
Africans as military soldiers and musicians. Knighton mentions that "Within these shared instrumental practices existed local variants or dialects; for example, the diverse ethnicities present in the Spanish Kingdom would inevitably have meant that certain instrumental sounds-such as those of the Arabic zambra-would have been more familiar there than elsewhere in Europe." She goes on to state, "...the sonajas and anafiles played and heard at the fifteenth-century court festivities held by the Constable of Castile, Miguel Lucas de Iranzo in the frontier-city of Jaen in distinctive ceremonies such as the re-enactment of the battles between Christians and Moors would have been familiar sounds throughout much of the Iberian Peninsula." ${ }^{25}$ Until the late-fifteenth century, Arab and Berber Muslims ruled parts of the Iberian Peninsula for hundreds of years, ${ }^{26}$ and Islamic and North African culture influenced some European societies until at least the Muslim exile from Iberia.

Beat Kumin's essay, “Masses, Morris and Metrical Psalms: Music in the English Parish, c. 1400-1600," discusses the roles that musicians held in English religious ceremonies. By looking mainly at churchwarden accounts, Kumin points out that church music has influenced much of England's parishes, even reaching rural communities. ${ }^{27}$ Organ builders and composers were often associated with churches. Churches were not only engaged in religious music but they were associated with social gatherings and secular entertainments for "neighbourly conviviality and fundraising necessity." Additionally, these gatherings included minstrels, morris dancers, mock lords and ladies, with other women as active participants, and were often held at

\footnotetext{
${ }^{25}$ Knighton, 98. Sonajas are ideophones of metal disks, and anafiles are a type of trumpet.

${ }^{26}$ Michael A. Gomez, Reversing Sail: A History of the African Diaspora, $2^{\text {nd }}$ ed. (Cambridge: Cambridge University Press, 2020), 65. Gomez notes that Muslims and Christians conflicted for rule over the Iberian Peninsula starting in the eighth century, and for nearly 800 years.

${ }^{27}$ B. Kumin, "Masses, Morris and Metrical Psalms: Music in the English Parish, c. 1400-1600," in Music and Musicians in Renaissance Cities and Towns, ed. Kisby, 70-81.
} 
communal "church houses." ${ }^{28}$ Not only was this a diverse group of people, but the musicians were sometimes lay people who climbed the hierarchical musical ladder. One such figure was John Taverner, who started his career as a lay clerk at a church and became a prolific composer. ${ }^{29}$ All this is to say that music across Europe had different meanings and significance depending on the social setting. In this case, these gatherings were social events with an egalitarian undertone.

As we attempt to consider the representations of black musicians in early modern paintings, we must first question whether iconography can be a reliable historical source. In the essay, "The Renaissance Slide Trumpet: Fact or Fiction?," Peter Downey argues that the slide trumpets represented in many paintings were not accurate depictions of the time because of the way these instruments were held as the musician played. ${ }^{30}$ The painting he refers to is by Hans Memling: Angel Musicians: two panels from a triptych (1460). To further his argument, he relies on surviving music sheets from the late fifteenth and sixteenth century arguing that such instruments could not produce the notes on the sheet. ${ }^{31}$

Yet other essays in this compilation attempt to dismantle Downey's argument. Keith Polk does just that in his essay, "The trombone, the slide trumpet and the ensemble tradition of the early Renaissance." 32 By using account records such as salary and livery expenses, Polk

\footnotetext{
${ }^{28}$ Kumin, 76.

${ }^{29}$ Kumin, 75.

${ }^{30}$ P. Downey, “"The Renaissance Slide Trumpet: Fact or Fiction?” in Instruments and Their Music in the Middle Ages, 383-389. In addition to his argument, he details the different trumpets and their uses. He highlights four instruments: the trombone, Italian trumpet, claret trumpet and S-shape trumpet. The S-shape trumpet was often used for military functions and courtly dances. The Italian and claret trumpet seemed to be used for ensemble purposes.

${ }^{31}$ Downey, 388.

${ }^{32} \mathrm{~K}$. Polk, "The trombone, the slide trumpet and the ensemble tradition of the early Renaissance," in Instruments and Their Music in the Middle Ages, 399-407.
} 
argues that slide instruments were in high demand. ${ }^{33}$ He furthers his arguments by pointing out that artists used the ideas and objects in their nearby environment and the experiences from their everyday life to characterize their paintings. ${ }^{34}$ So, if there is any merit to Downey's argument, namely that depictions in art of musicians and instruments could be unreliable, the question still remains, why would artists depict black Africans in their paintings? Polk makes a more compelling argument in the usage of iconography, because not only did the artists tend to use their surroundings for their paintings but they often used models as their subjects. For example, Peter Paul Rubens used "an anonymous African of whom nothing is known except that he posed as a model for Rubens between 1613 and $1615 . " 35$ Apart from paintings, literature and historical data also highlight the presence of sub-Saharan Africans as being a prominent component to Spanish music and entertainment. ${ }^{36}$ Some Spanish literature displays the stereotype of black Africans as having a "natural tendency... to become musicians." 37 Aurelia Martin-Casares, for example, notes that, "One can find reports of musicians, or popular feasts where black African dancers participated, in the municipal archives of numerous cities, particularly in the southern half of the Peninsula." 38

\footnotetext{
${ }^{33}$ Polk, 402.

${ }^{34}$ Polk, 405.

${ }^{35}$ E. Kolfin. "When Africans Became Black, 379-392.

${ }^{36}$ A. Martin-Casares and Marga G. Barranco, "The Musical Legacy of Black Africans in Spain: A Review of Our Sources," Anthropological Notebooks, vol. 15, no. 2, (2009): 51-60. One dance that is attributed to sub-Saharan Africans is known as the guineo. Martin-Casares notes, "The guineo was defined as 'a dance of quick and prompt movements, may have been brought from Guinea and is danced by blacks."' Another dance said to be of African origin is the zarambeque, "which 'was considered a very lively, boisterous dance."'

${ }^{37}$ Martin-Casares, 54. In this section, Martin-Casares discusses the novel, El celoso extremeno (The Jealous Estremaduran) (1613), written by novelist and poet Miguel de Cervantes. She mentions that, "In this comedy, Luis, a stableman determined to learn how to play the guitar, is an enthusiast of music."

${ }^{38}$ Martin-Casares, 55.
} 
Thus, when we consider urban and courtly spaces and the role of music within them, we can see how integral music was to various European societies. While many archives neglect the individual, we can still get a sense of the socioeconomic position musicians held. Coupling this information with paintings, we can begin to explain and interpret the depictions of Africans in iconography. If painters used models, and were gathering the subject matter from their environments, it becomes more plausible that black Africans were indeed musicians, as the depictions in paintings suggest.

\section{Livelihood: Black Africans in European Societies}

Since each person represented in these paintings appears to be based on living human beings, as the detail in facial and body gestures suggests, one must wonder what the living situation, the livelihood, and socioeconomic status would have been for black African musicians in early modern Europe. Some historians make the argument that these representations contributed to the stereotyping of Africans as entertainers. Although this may be the case, and in some paintings, black musicians are represented in an exotic fashion, it is not necessarily the case that they are being disparaged or marginalized in all of these images in the context of their time. A more accurate perspective would be to view them as active members of their respective societies, and this paper seeks to treat them as such. From this perspective, we can ask questions that tell us about their role in society. Where did they live when not working/performing? Did they receive compensation for their work? Were there chances for 
social mobility? Were there signs of cultural retention among black Africans? To answer these questions, we must look at the literature and documentation produced in this time.

Africans were usually brought to Europe as enslaved people, often to signify their master's wealth and prestige. To own a slave, one must have been financially well-off, as purchasing them and sustaining their health were expensive. Annemarie Jordan notes, "Prices for slaves in the early decades of the sixteenth century started at 15,000 reais each, tripling by mid-century to 45,000 to 50,000 each and later stabilizing at between 15,000 and 30,000 reais by 1570 s." ${ }^{39}$ Because enslaved Africans represented the power of European elites, slave owners took great care of their subjects' physical wellbeing, marking them as status symbols. This is evident in the way they were treated, as the master provided room and board. ${ }^{40}$ As David Northrup remarks, "More and more Africans were brought to England, where it had become a desirable mark of distinction by the 1590s for elite families to have an African or two among their servants." ${ }^{11}$ It makes sense that a master would want to invest in their slaves' health because they provided labor, financial support and clout. Owning black slaves and hiring black servants signaled one's prestige. ${ }^{42}$

When we consider the people in these paintings as more than subjects for artists, we can begin to think of them as actual humans with more to offer to their respective societies than just how they have been depicted. We can see them as having experiences, families, and

\footnotetext{
${ }^{39}$ Annemarie Jordan, "Images of Empire: Slaves in the Lisbon Household and Court of Catherine of Austria," in Black Africans in Renaissance Europe, ed. Earle and Lowe, 157.

${ }^{40}$ Saunders, A Social History of Black Slaves and Freedmen in Portugal, 1441-1555, 96. Saunders' review of "royal accounts and clothing orders provide most of what is known about sleeping accommodations for slaves." He states that it cost 1,216 rs for beds which slaves slept on.

${ }^{41}$ David Northrup, Africa's Discovery of Europe, 1450-1850, 3rd ed. (Oxford: Oxford University Press, 2014$), 7$.

42 Saunders, 66.
} 
relationships that go beyond servitude. As Habib discusses the personal staff of James IV, he mentions an African drummer, "morien taubronar," who received compensation from the royal disbursement from Scotland on the $12^{\text {th }}$ of April, $1504 .{ }^{43}$ This drummer is also noted to have received multiple payments that contributed to his family's wellbeing while he was in service of the king. ${ }^{44}$ Enslaved Africans and black servants were often able to move about town, and in some cases, found work for themselves outside their masters' home. Saunders mentions, "The cities, particularly Lisbon, provided the most diversified opportunities for masters who wished to make money from their slaves' labour, whether by employing the slaves directly, hiring them out, or allowing them to carry on a modest business of their own." ${ }^{45}$ Enslaved people earned and kept a portion of the money, which contributed to the rising demographic of freed men in Portugal. 46

These Africans would have been considered subjects of the local elites, similar to most of the poorer population. Yet, their cultural and social practices were valuable to elites and admired by locals. Northrup notes that, "One area of cultural retention was music. African musicians and dancers were in great demand in sixteenth-century Iberia, and enthusiasm for black musicians remained common in Europe for centuries." 47 Thus, the influence of black Africans was felt along all social lines. Jordan remarks that, "Slaves with musical and dance

\footnotetext{
${ }^{43}$ Habib, 29.

${ }^{44}$ Habib, 29. As Habib observed the economic records he notes, "The standing and support of this black man has at the Scottish court is reflected in the range of payments made to him or for him, beyond his compensation for services rendered... this African has a family, and when he is away on service to the king his family is provided for, as on 14 November 1504, when 14 shillings are paid to him, a payment that is repeated two years later on March 1506/07, and on 22 May 1506/07."

${ }^{45}$ Saunders, 72-74.

${ }^{46}$ Northrup, 8.

${ }^{47}$ Northrup, 8.
} 
abilities were recruited for court fetes, entertainments, royal entries and for duties in the royal chapel." ${ }^{48}$ On some weekends, Africans were allowed to have social gatherings with other enslaved people in their communities. These gatherings consisted of music and dance. ${ }^{49}$ Younger Europeans were drawn to such events because it offered some excitement to their lives. This is evident in the laws that were enacted to prohibit such gatherings, because the civic leaders feared that these events were corrupting their young souls. As Saunders' states, "Blacks sang, danced and played instruments at their own gatherings, held during their time off work. Unfortunately, most of what we know of the blacks' festivities comes from legislation forbidding them, but at least we know what blacks liked to do when given the opportunity."50 As discussed later in the image analysis section, court events valued the ways in which sub-Saharan Africans played music. Saunders notes “...their musical skills... were most in demand."51 Several historians mention that Africans were coveted for what Europeans believed to be their rhythm and natural ability with instruments. Kate Lowe remarks that, "European records constantly testify to the belief in black Africans innate sense of rhythm... From the midfifteenth century onwards, documentary and visual sources chart the employment (in particular) of black drummers and black trumpeters, mainly (but not solely) at Renaissance courts, where they were in great demand at public and private celebrations and entertainments." 52 This connects directly to the paintings analyzed later in this paper, as in

\footnotetext{
48 Jordan, 158.

${ }^{49}$ Saunders, 106. He notes that, “...blacks of Santarem frequently obtained permission from their masters to celebrate on Sundays and religious festivals by inviting other blacks to the feast." In this context, blacks were displaying solidarity with people based on skin tone.

50 Saunders, 106.

${ }^{51}$ Saunders, 105.

52 Lowe, 35.
} 
most of the depictions the black figures are either playing drums or horn instruments, and in

one case, the figure is playing both instruments at the same time (see Figure 8).

As mentioned above, discrimination in the early modern period was based more on

ethnic and religious differences than on skin tone:

From the beginning of the $16^{\text {th }}$ century, cultural and religious repression was centred on the Moorish community, whose dances and musical forms, such as leilas and zambras were strongly prohibited. In contrast, the sub-Saharan population settled in Early Modern Spain had a certain degree of freedom to express itself symbolically. In fact, Nunez Muley, defender of the Moorish community in front of the Spanish Crown, in his memorial of 1566 complained that the blacks and slaves from Guinea were allowed to sing and dance and play music with their own instruments and also to use their own languages, while the Moorish community was increasingly culturally repressed. ${ }^{53}$

This quote contains several important elements, such as who was most marginalized by the restrictions imposed on them. The tension observed in this quote is between religious differences, between Islam and Christianity. Many slaves from sub-Saharan Africa converted to Christianity, a fact evident in the baptismal and parish records. ${ }^{54}$ The envy Muley displays emphasizes religious discrimination. And in other parts of Renaissance Europe, resentment and envy towards black Africans was present. One black man perfected his needle making technique, which garnered resentment from some Europeans because he would not share the skill with others. ${ }^{55}$ This highlights the acculturation black Africans experienced in European societies. They are often depicted wearing European garb with symbolic elements suggesting

\footnotetext{
53 Martin-Casares and Barranco, 52.

$54 \mathrm{Habib}, 16$. Habib details his methodological and analytic approach. The primary documents he uses are government records, personal records, and parochial church notations to identify the black African presence in London.

${ }^{55}$ Habib, 44. Habib remarks on the resentment and animosity steered towards the black man observed in William Harrison's magisterial account as he mentions, "would not teach his art to any."
} 
cultural blending. And, there are many signs that point to them expressing African cultural practices as well.

Image Analysis

In our sample size of twenty-two paintings, several trends concerned with black musicians can be observed. Additionally, several pieces of art depicting musicians from West Africa can be compared to European art, which further links the two continents. In many of the European paintings, the black figures are holding or playing instruments such as drums or wind instruments. Often, they are depicted on horseback. In these depictions, they are all represented as men. ${ }^{56}$ Not only is skin color a signifier, but also phenotypical characteristics are applied by the artists, such as differences in hair type (coarse or kinky), facial and body features, and even stature. As Elmer Kolfin notes, Dürer for example, "gave the African Magus short curly hair and consciously rendered him in profile to bring out the flat nose, full lips and high forehead to depict as clearly as possible what he considered to be typically African features. ${ }^{\prime 57}$ To the artist these were obvious means to define their African subjects. European artists improved their techniques and used cross-hatching to better show gradations of shade. African artists achieved a similar effect by using metals like iron and bronze in their artworks. Whereas the techniques used to create their artwork have differences, there are similarities within the compositions such as the detailed rendering of human figures, depth of field,

\footnotetext{
${ }^{56}$ There are plenty of paintings that depict African women, just not in the context of musicians. There is, however, great opportunity to study African women in early modern history.

${ }^{57}$ Kolfin, 379.
} 
allegory and symbolism. Additionally, both African and European artists rendered their foreign subjects in profile view. Both also used art as a means to record historical events.

A comparison with African art depicting musicians would be useful for drawing connections and observing continuities between the two continents. In the late-fifteenth century, Portuguese explorers introduced commodities and foodstuffs with the rulers of the Kingdom of Benin in exchange for African artefacts. ${ }^{58}$ At the Metropolitan Museum of Art in New York, a statue labeled "Horn Player" depicts an African from Benin. This piece has been dated between 1550-1680 (Figure 1). Among the Edo people, only the ruler can commission or give permission for such art to be created. ${ }^{59}$ This suggests that art played an important role in this African context. Indeed, African art was used to document historical events surrounding the kingdom. Ananwa uses the term "visual history," which is fitting because throughout most of recorded history, only a select few could write, let alone understand the texts, as many people were illiterate. Therefore, visual art is the language of understanding in a world where only the powerful had an education. ${ }^{60}$ As for the figure, he has large eyes and a wide nose. The figure is depicted wearing an elaborately designed skirt with the image of a leopard. With both of his arms, he is holding a flute pressed to his lips, and it seems that he is actively playing the instrument. But it is the phenotypical depictions and jewelry that let the observer know that

\footnotetext{
${ }^{58}$ Chika Joseph Ananwa, “Internationalisation of Benin Art Works.” Journal of Humanity, vol. 2, no. 1 (2014), 48. Ananwa notes, "In 1485... John Alfonso D' Aveiro visited Benin City bringing with him coconuts and guns.... The Benin artefacts were important because it prevented the Benin from depending economically on the Portuguese." ${ }^{59}$ Accessed online at: https://www.metmuseum.org/art/collection/search/310753.

${ }^{60}$ Ananwa, 46. Ananwa remarks, "The ancient inhabitants of the Benin Kingdom were non-literate as such there are lacks of supplementary written materials on their artefacts. Conversely every single art item they produced was history on its own and in most cases, artefacts tell more accurate stories of events, time and place than written version."
} 
this figure is African. The jewelry, attire, and the instrument speak to a musical culture and identity among West African people in the early modern period.

If Africans rendered a portion of their history in the form of visual art, then the Benin Kingdom plaques display a more robust story. Kate Ezra underscores the purpose of plaques in West African courts as she notes, "The palace, a vast and sprawling agglomeration of buildings and courtyards, was also the setting for one of the most fascinating art forms created in Benin, rectangular brass plaques whose relief images portray the persons and events that animated the court." ${ }^{61}$ Only the king could commission such artwork, which he approved to document important ceremonies and events, as Kate Ezra quotes in a document produced by Olfert Dapper: "The King shows himself only once a year to his people, going out of his court on horseback, beautifully attired with all sorts of royal ornaments, and accompanied by three or four hundred noblemen on horseback and on foot, and a great number of musicians before and behind him, playing merry tunes on all sorts of musical instruments." 62 If we accept artwork as a legitimate form of historical storytelling, then the Benin plaques deserve further analysis. Another piece of untitled artwork dated back to the mid-sixteenth to seventeenth century from West Africa, from present-day Nigeria, is an intricate plaque designed by an unknown Edo artist (Figure 2). ${ }^{63}$ What seems to be represented in the foreground is a large warrior figure holding a spear in one hand and a shield in the other. To the left and right of his head are two figures that

\footnotetext{
${ }^{61}$ Kate Ezra, Royal Art of Benin: the Perls Collection in the Metropolitan Museum of Art (New York: Metropolitan Museum of Art, 1992), 117.

62 Ezra, 117.

${ }^{63}$ Accessed online at: https://africa.si.edu/collections/view/objects/asitem/search@swg'plaque'/8/titleasc?t:state:flow $=90 c 6 c d 5 c-f 63 a-47 e e-a 416-649 d 4725 c 145$
} 
are believed to be depictions of Portuguese traders. ${ }^{64}$ Ezra notes that Benin artists did not limit their depictions to their Edo subjects, but also incorporated portrayals of Portuguese traders, seamen, and soldiers. ${ }^{65}$ In the plaques, the Portuguese are rendered in profile view, a technique used by European artists to depict phenotypical differences. The smaller figures to his sides may be seen as standing in the background. They may also be rendered smaller to amplify the significance of the warrior. The smaller figure next to the warrior has his genitals exposed. In West Africa, nudity was a common practice. This perhaps may connect to the way European artists exaggerated their subjects' genitals in an effort to implicate symbolic meaning. ${ }^{66}$ The figure to the bottom right seems to be playing a horn. The figure in the bottom left is said to be beating a gong. These two figures have similar faces depicted on their attire, which seems to be that of an exotic cat, a motif also expressed in connection with black African musicians in European art. It is apparent that music and combat are intimately linked in this plaque. Thus, music and art are two cultural practices that share similarities between the two continents. As we will see, music and African musicians play a significant role in European military and combat settings as well.

When examining black African figures in European art, signs of their "otherness" can be seen by the cultural ties to Africa in depictions of headdresses, jewelry, clothing, and animal fur.

\footnotetext{
${ }^{64}$ Accessed online at: https://africa.si.edu/collections/view/objects/asitem/search@swg'plaque'/8/titleasc?t:state:flow $=90 c 6 c d 5 c-f 63 a-47 e e-a 416-649 d 4725 c 145$

${ }^{65}$ Ezra, 128.

66 James J. Bloom, 77. "The Role of Painters before the Rise of Painting: The Master of Frankfurt's Festival of the Archers," Netherlands Yearbook for History of Art / Nederlands Kunsthistorisch Jaarboek, vol. 59, no. 1, (2009): 7089. Bloom notes, "The figure of the Master of Frankfurt is specifically juxtaposed with the fool in cockscomb, who not only sports his cock on his head but has also slung his doedelzak-a notorious phallic symbol-round his back, positioned in anatomical opposition to his own phallus and thus externalizing his emasculation." If we subscribe to this narrative, then it is likely that the black Africans genitals have symbolic meaning as well.
} 
In many paintings, the black figures are central to the composition, making them difficult to miss. Additionally, they stand out even more because they are usually the only black figures, or underrepresented, in the paintings. Within the composition of the paintings, there is usually one black African, or they are shown clustered together, in both cases visually isolated.

The black figure represented in The Westminster Tournament Roll (1511) is believed to be John Blanke (Figure 3), who is indicated by payments he received recorded in the Treasurer of the Chamber account noting that he earned $8 \mathrm{~d}$ a day. ${ }^{67}$ This tournament was commissioned by Henry VIII in celebration for the birth of his son and celebrated for two days. In the roll, Blanke is depicted with dark skin riding horseback with two white musicians on each side of him. These three musicians share several similarities, as they are all wearing identical attire and blowing into an s-shaped trumpet that flies identical flags; their horses are depicted holding the same pose. This image suggests that Blanke would have received the same musical and equine training as his peers. ${ }^{68}$ Horseback training and musical training takes a wealth of time and effort. They also take organization and cooperation. All this means that these musicians on horseback spent a lot of time together, suggesting that they were on par in terms of social status. But there are stark differences in his portrayal, as well. For instance, Blanke is mounted on a black horse, which sets him off visually from the other riders. The two white musicians have similar hairstyles and rosy facial pigmentation. Besides skin color, the other difference that further sets them apart is his headgear. The white men have identical hairstyles, but

\footnotetext{
${ }^{67} \mathrm{Habib}, 40$. John Blanke was received compensation for his work as a trumpeter for several years. Habib notes, "Musicians' payments in the account of the Treasurer of the Chamber record several payments to him of 8d a day, going back to the reign of Henry VII. He is named, for instance, in the Exchequer roll of 1507 as having been paid on 7 November 20 shillings or 430 pounds in today's currency."

${ }^{68}$ Accessed online at: https://www.nationalarchives.gov.uk/pathways/blackhistory/early times/blanke.htm. The tournament roll is sixty feet in length and John Blanke is said to appear twice on it.
} 
Blanke is depicted wearing a green cap or maybe a headwrap of some sort. Kate Lowe suggests that this article of clothing may have cultural ties to Africa. ${ }^{69}$ Knighton suggests that he is wearing a turban. ${ }^{70}$

The importance of black musicians in formal events is corroborated with other artistic depictions of black Africans in early modern times. To "keep" and house a black musician was not taken lightly and required the approval of an emperor. As Schreuder notes, "the Emperor Ferdinand II (1578-1637) granted that privilege to Count Christian of Waldeck (1585-1637)."71 Harmenszoon van Rijn Rembrandt's (1606-1629) sketch, Two Negro Drummers on Mules (1638) (Figure 4), suggests a blend of European and African cultures. Rembrandt attended the wedding festivities of Johan Wolfert van Brederode (1599-1655) and Louise Christina van Solms (16061669) at the Stadholder's court in The Hague in $1638 .{ }^{72}$ It is likely that he observed the two African drummers at this event. So, from the low viewpoint that he drew this sketch suggests that the two black drummers were performing in front of his very eyes. ${ }^{73}$ The two African drummers were mounted on top of mules as both musicians seem to be actively playing their instruments, indicative by their body language. Around the drums seems to hang drapery resembling precious cloth, a commodity held in high regard in west Africa and Europe. The mounted black man in the middle of the painting seems to be wearing a skirt decorated with feathers. Their faces are depicted in the profile view, highlighting their facial features. Their

\footnotetext{
${ }^{69}$ Lowe, 39.

${ }^{70}$ Knighton, 116.

${ }^{71}$ Esther Schreuder, Black Is Beautiful: Rubens to Dumas (Amsterdam: De Nieuwe Kerk; Zwolle: Waanders, 2008), 259.

72 Schreuder, 259.

73 Schreuder, "'Blacks' in Court Culture in the period 1300-1900 Propaganda and Consolation," in Black Is Beautiful, 28.
} 
foreheads are covered but the man in the front has a large nose and full lips. The man in the background appears to be wearing headgear with feathers. One feature which is very obvious is the earrings they both are wearing, which also may be visual ques implying cultural ties to Africa.

Although the characters in the foreground are drawn in a fair amount of detail, this seems to be a relatively quick sketch of a scene. Thus, Rembrandt paid some attention to the background but there is little definition. Yet behind the two drummers, there is an object which resembles a canopy. There is an undefined shape in the background that looks like a human head, which signals there are more people involved in this entourage. This suggests that the men are leading the way for an important figure, quite possibly a member of the wedding party. As evident in the other paintings examined, music is associated with ceremony. Their garb, their skill on horseback and the decorations all suggests that these men were professionals using proper equipment. ${ }^{74}$ Their body language signals comfort and confidence in their roles which would be needed when riding on a large animal while both hands are occupied by playing their instruments. Drummers and trumpeters in general were held in high regard, and as Schreuder notes, "Black drummers and trumpeters were even more impressive."75

In the Illustration for Certamen (1672) (Figure 5) drawn by the artist David Klocker Ehrenstrahl (1629-1698), he uses the cross-hatching technique with amazing execution. To the left of the midpoint of the drawing, we see three men with trumpets on horseback. They are

\footnotetext{
${ }^{74}$ Schreuder, 28. She notes that, "The kettledrums appear to be of the German Kessel type."

${ }^{75}$ Schreuder, 259.
} 
traversing what looks like bare ground. The two men in the foreground are clearly European. It is questionable if the man in the back has darker skin. The techniques used by the artist can be misleading; the artist may have intended on depicting him as European, though, because of the similarities he shares with the other two figures. Their horses are all adorned with scaly armor, which matches the pattern of the leader's attire. Additionally, they are all wear similar headdresses.

Central to the composition of the drawing are two black figures. One leads the horse while the other is on horseback playing the drums. When comparing the differences between the Europeans and the Africans, clear distinctions can be drawn. First and most obvious is the difference in skin color. Second, while all the Europeans have on helmets fashioned with what looks like feathers, the African figure has distinctive black feathers, which may be a sign of an exotic bird, sticking out of his headwear. Another difference is between the horse's adornments. They all have similar headwear. Yet the horse the African figure sits upon lacks any armor. And on his horse is a pelt that looks like exotic cat skin, possibly from a leopard. As we saw earlier, both African and European artists included exotic cat imagery into their artworks, suggesting mutual cultural exchanges. With all the differences described, they all seem to be playing their role in unison. The drummer seems to be mid-stroke as he plays the beat, while the three trumpeters play their instruments. They all seem to be marching in the same direction while a man on horseback with a spear leads the way. Again, this is another example where music and military imagery merge together.

Yet military or ritual settings are not the only occasions when black musicians are represented. Attributed to Cristovao de Figueiredo and Garcia Fernandez, The Santa Auta 
Retable (1525) (Figure 6), housed in Lisbon, Museu Nacional de Arte Antiga, supposedly depicts the union of Catherine of Austria and King Joao III, ${ }^{76}$ although Knighton argues that the figures depicted getting married are Saint Ursula and Prince Conan. ${ }^{77}$ The larger context of the painting appears to be the union between two royal families. All the women seem to have similar facial features, which suggests one of two things: that these women are members of the same family, or the artists used the same model's facial structure to characterize the three women. They have the same skin tone; same round-shaped head; and same forehead. The bride and the woman to the far right even have the same facial expression. All the men are positioned on the left side of the painting, while all the women are staged on the right. There is also a religious element depicted here. An angel hovers above the couple and seems to be bestowing a blessing upon them. A man between the couple is wearing a bishop's mitre, confirming him as the religious figure who approves the marriage.

In this incredibly detailed painting, six wind instrument players are unmistakably represented as black Africans. Annemarie Jordan points out that all the different types of instruments being used in this painting have been identified. ${ }^{78}$ This strongly implies that this image was based on actual people and events, and the artist used his surroundings to add to the composition. The way they are dressed and the situation in which their skills are called upon suggests that these musicians were highly professional and organized with their musical talents. Their red and blue garb is formal and uniform, signaling acculturation and court usage. Their instruments are raised and their facial expressions imply that they are in concert with

\footnotetext{
76 Jordan, 158.

77 Knighton, 117.

78 Jordan, 159.
} 
their individual tasks. The musicians are physically positioned above the scene below. Behind the six musicians ominously stands a white man. The white man's role is unclear; he may be the conductor or supervisor.

Thus, the wedding was an important affair with a lot of organization and planning. By the looks of their clothing, it seems to be an expensive gathering with important and influential figures. Considering all the preparation that went into this event, it can be argued that the black musicians would have been well-trained and highly skilled. They must have had plenty of time to practice and prepare for such an occasion for the simple fact that they were playing at this wedding. Creating music worthy of such an important event requires a level of training and professionalism that highlights their skills and talents to produce pleasing melodies. Knighton suggests that "the minstrels may be six of the seven named in the will of dom Jaime of Braganza (d. 1532), who spent much of his adolescence at the Castilian court."79

A black musician likewise appears in Italian painter Giulio Romano's Marriage Feast of Cupid and Psyche (1530's) (Figure 7). There are only two sources of sound production in this painting, which depicts a lavish celebration. Central to the painting is a white woman who seems to be crashing cymbals. The other is a black figure blowing into a wind instrument. The figure is un-mistakenly African, as evident by his skin tone and coarse hair.

The muscle definition and anatomic accuracy suggests that some of the figures painted are representations of human subjects. Even the smaller figures' statues are proportionate. The animals look incredibly life-like. In their facial expressions is a general sense of happiness and excitement. In the foreground we see two goat-like figures, or satyrs. They are characterized

\footnotetext{
79 Knighton, 117.
} 
with long ears and horns on their heads. The one in front of the table appears to have a similar skin tone as the Europeans in the painting. Upon closer inspection, we can see that both their genitals are exposed. The genitals of the one in the front are hardly detectable. Yet, as we shall see, similarly to the black musician in The Archers' Festival (see Figure 8), the darker skinned figures' genitals are far more exaggerated than the others. He seems to be in a seductive engagement with one of the women. This suggests the hyper-sexualization of the black male figure.

In our final example, a black musician also appears in a painting by the Master of Frankfurt (1460-1533). The Archers' Festival in the Garden of Their Guild (1493) (Figure 8), depicts a lively scene characterized by a diverse set of figures. It is believed that the Antwerp guild of the Old Arabalest commissioned this work of art for a celebration after the archers' competition. ${ }^{80}$ This appears to be a private gathering as the entrance to the area is guarded by men wielding weapons. In the foreground we see a younger person and a woman trying to squeeze through the fence. One figure from within the gathering is trying to give a child a piece of fruit outside the festivities. We see in the middle of the painting a key figure holding what seems to be a chalice in his hand as a person to his right offers him a drink. He is surrounded by a small crowd of soldiers and archers. ${ }^{81}$

There are many forms of "otherness" represented in this painting. There is a black musician, a jester and another oddly dressed man in the center of the painting. ${ }^{82}$ On the jester's

\footnotetext{
${ }^{80}$ Accessed online at:

http://vlaamseprimitieven.vlaamsekunstcollectie.be/en/search/node/festival\%20of\%20archers.

${ }^{81}$ Bloom, 74. Bloom identifies this figure as Peter de Gramme, a city alderman in Antwerp.

82 Lowe, 37. Lowe remarks on the black musicians clothing, equipment and position within the composition along with the fools that are clustered central to the painting.
} 
left arm rests two crows. Most of the women in the painting have similar skin tones. Yet a variety of shades are cast upon the different male figures. There is a figure that seems to be depicted as a Native American under the tree to the observer's left. He seems to be abnormally tall, as he easily reaches to pick fruit from the tree. In the tree is a smaller person that seems to be picking fruit (maybe pears), and this is evident as there is a woman holding a sack full of the fruit. The tree to the right has an ominous brown skinned figured with his face partially covered with possibly a beard.

Under the tree to the left is a black figure. He is wearing a white cap and has an earring. His attire is mostly white with some elaborate frills coming off his sleeve. He is wearing tights, which exaggerate his genitalia. Bloom observes that the artist makes allusions to emasculating himself within the composition. It appears that the Master of Frankfurt depicted himself in the painting. He is believed to be directly underneath the fool in the bird costume. Bloom notes, "As if to reassure himself, the fool grasps the instrument's chanter while its drone and bag hang limp and lifeless between his legs, the very tip of the drone drooping just behind the painter's head." ${ }^{83}$ Bloom makes no mention of the sexualization of the black figure, but given that this painting is rife with symbolic meaning and allegory, we can infer that the artist made allusions towards the black figure by surrounding him in symbols. For example, right above the black figure's his head and very close to him is an animal figure that resembles a fox, possibly signifying something threatening or sly about the black musician. ${ }^{84} \mathrm{He}$ is depicted carrying a

\footnotetext{
83 Bloom, 77.

${ }^{84}$ Accessed online at: http://bestiary.ca/beasts/beast179.htm In medieval imagery, foxes are said to be crafty and deceitful animals. It is possible that the artist intentionally positioned the fox close to the black figure to convey such a message.
} 
drum and holding a flute in his left hand. Upon closer inspection, he seems to be playing the flute, as his lips are pressed on the mouthpiece. With his left hand, his fingers cover specific holes as one does when playing the flute. His right hand holds a drum stick, which seems to be in motion to make a beat. Another noticeable detail is that other figures depicted in the painting have instruments. Yet, they are not playing them. Only the black figure is depicted as producing musical sound.

Despite all the differences between these figures in the painting, they all seem to be enjoying their time within the context of the composition. This speaks to the cosmopolitan nature that characterized many societies of the early modern period. Everybody within the fenced area seems to have a role to play or is a member of the guild, which highlights the communitarian aspect of such societies. Nowhere in the painting do we get a sense of overt hostility, although the demonic fool figures and black musician may be somewhat threatening, as implied by the allegorical messaging. Bloom notes that this painting is packed with symbolic devices, so it might "at first glance like a love garden, upon closer inspection, also a battle scene." ${ }^{85}$ Under the tree to the right, there is a couple kissing. There is an odd interaction with the three figures to the left under the same tree. Even the people outside the gathering receive food, as the ground is littered with fruit. At first glance, it seems to be an exciting and intimate event.

What does deep analysis of these paintings tell us about these societies? For one, the artist must have been very skilled to capture the likeliness of his subjects. This suggests that the figures in the paintings were inspired by actual human models. Unlike a photograph, to

\footnotetext{
${ }^{85}$ Bloom, 75.
} 
construct such a lively scene in painting one must use their imagination, as the figures are not static. But much like a photograph, these paintings capture a moment in time to present a specific message to their audience. Sometimes these paintings were an amalgamation of events that constructed a specific narrative. So, even if these black figures were imagined, the artist put a lot of thought into their representations. Their clear phenotypical depictions suggest that these figures walked among the artists, and that the artists characterized them as they were existing with the context of their time.

\section{Conclusion}

When coupling art with primary sources, it becomes apparent that the historicity of a given image can be determined by visual representations. By observing the many early modern artworks from Africa and Europe, it is clear that black Africans played important roles in their societies and contributed not only economically, but culturally. Black Africans had social lives. They were paid adequate wages, and even ran modest businesses of their own that often led to manumission if they were held in bondage. Their abilities as musicians required rigorous training and substantial skills. Many were public figures, performing in a variety of settings, making them highly visible to the population. Black musicians were sought after and used in high-profile events, which marked the emperors or nobility's prestige. The artists that portrayed them paid close attention to their adornment; therefore, it was not just their skin tone that signaled difference but their attire often underscored their foreignness. 
Black Africans in Renaissance Europe have been mentioned by historians and other scholars for decades, ${ }^{86}$ and these paintings have been on display for centuries. Yet mainstream academia has largely ignored their presence. Pairing together the research of literature and primary documents with Renaissance paintings, a new narrative emerges. This helps us disassociate Africa from Europe as being synonymous with slavery, or at least offers a different framework for talking about enslaved people in the early modern period. This paper attempts to humanize Africans and their lives in an interconnected world. We have seen that black Africans played significant musical roles in European societies. Not only do paintings show this, but so does the documentation. The order in which these works of art appear in this paper emphasizes the possible exchange of art techniques between Africans and Europeans, suggesting that these cultures were highly involved with and influenced each other. Additionally, African political and social practices such as pawnship implies structural exchanges between them. It is possible that European and African musical practices shared and engaged with each other. The methodology used in this study can be applied to other aspects of the black experience in European societies, such as their participation in military practices. Statues and paintings across early modern Europe depict black Africans in military roles. For instance, displayed at the Metropolitan Museum of Art, a black African appears in a painting titled Saint Maurice (ca. 1520-25), by the artist Lucas Cranach the Elder. ${ }^{87}$ This order also highlights the thin lines between admiration, eroticism, and possible sinister undertones.

\footnotetext{
${ }^{86}$ Nubia, 2. He notes that many authors of African descent have written about Black Africans in the early modern period. But their works have been neglected due to institutional discrimination that often privileges Eurocentric narratives over other ones.

${ }^{87}$ Accessed online at: https://www.metmuseum.org/art/collection/search/439081. The image's description notes Saint Maurice started being represented as black under the reign of Emperor Friedrich II (1194-1250). It goes on to
} 
Theory helps us imagine what their lives were like in the context of their time. We do the past a great disservice when we project our language onto the lives of people that existed well before the terminology arrived. The structure of their societies differs drastically from ours, not only in time but as well as in space. For instance, the meaning we tend to ascribe to nationalism today, where land and nationality are often tied to racial identity, would not fit into early modern concepts of identity as we have seen that many Renaissance European societies were cosmopolitan. These societies were highly hierarchical and each subject in the order had a role to play where prejudices based on skin tone were in its infant stages. The social constructs in today's world are far more standardized and institutionalized than in previous centuries. They were larger communitarian societies with different political, social and economic structures that are unfamiliar to us. This does not mean we should not critique the past with the information we have now. We see how some of the erotic and prejudicial tropes aimed towards black Africans in these paintings have carried on well into the future. One could make the argument that these prejudices influenced certain aspects in modern life that now adhere to Western philosophy.

This philosophy often views the past through a Eurocentric, post-colonial perspective, which tends to only associate the African presence with plantation slave labor. Therefore, the past is often viewed through the limited Marxist and economic points of view. By broadening the theoretical frameworks with which we use to interpret the past, we can attempt to restore 
the humanity that has been stripped away from black Africans and highlight the significance of their role in shaping modern society.

\section{Figures}

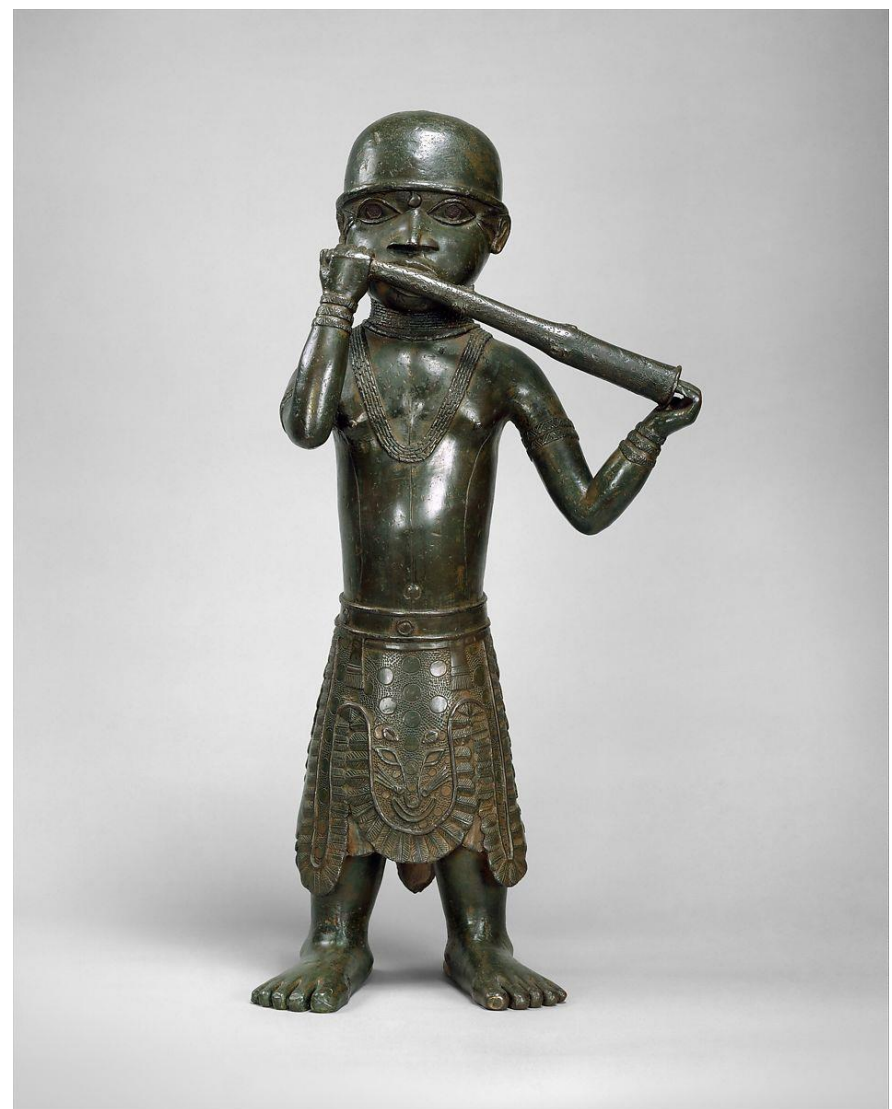

Figure 1. 


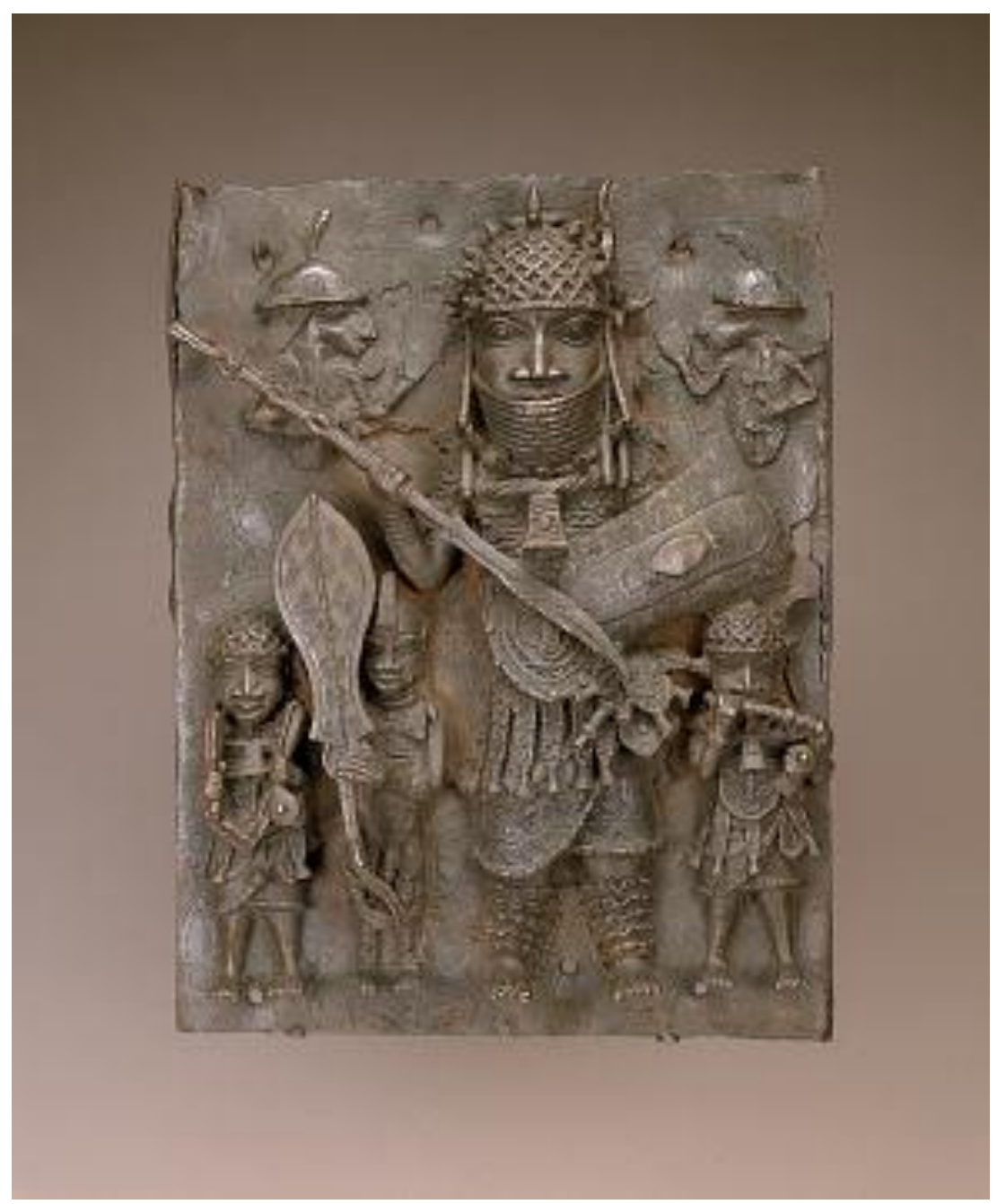

Figure 2. 


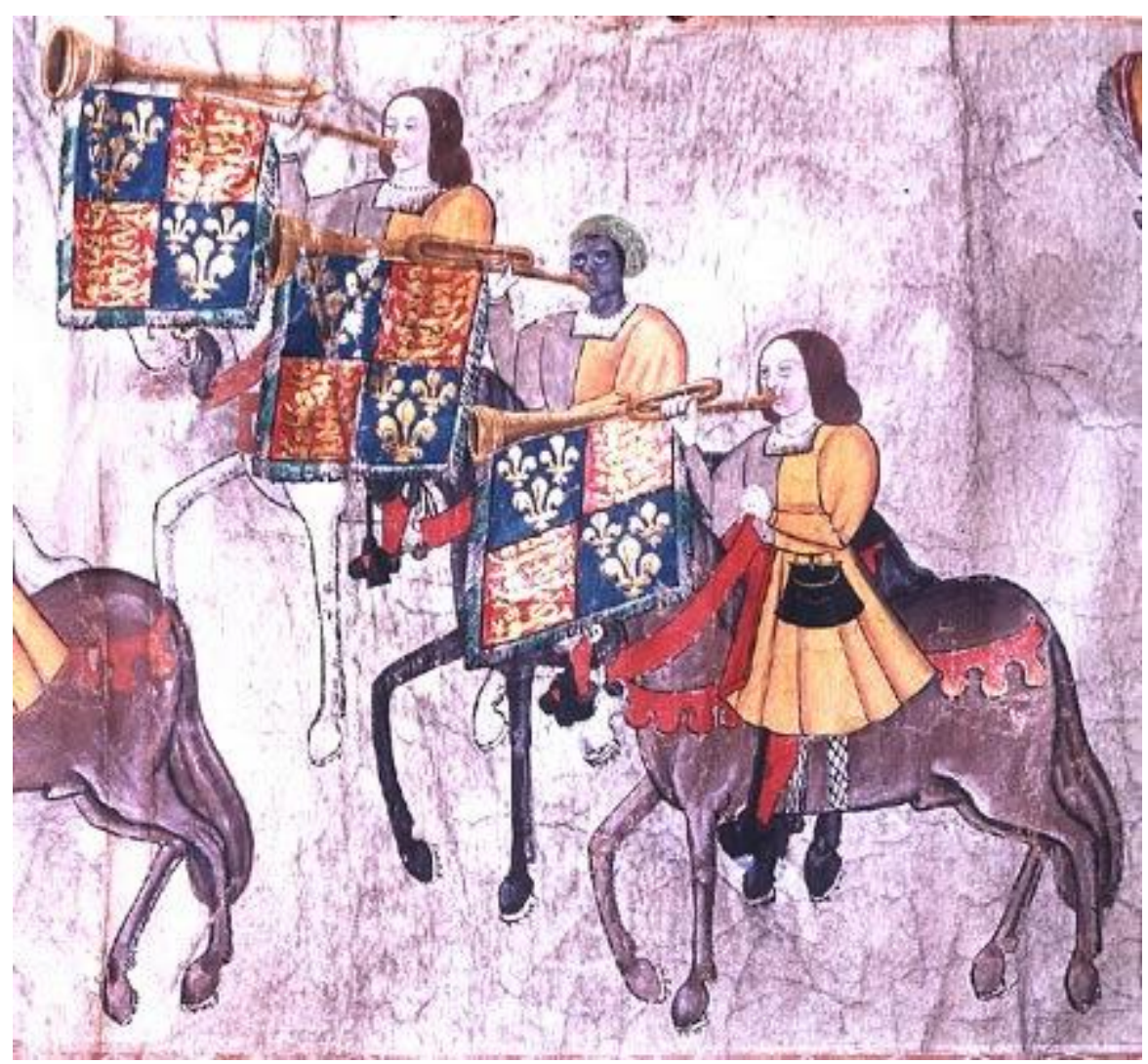

Figure 3. 


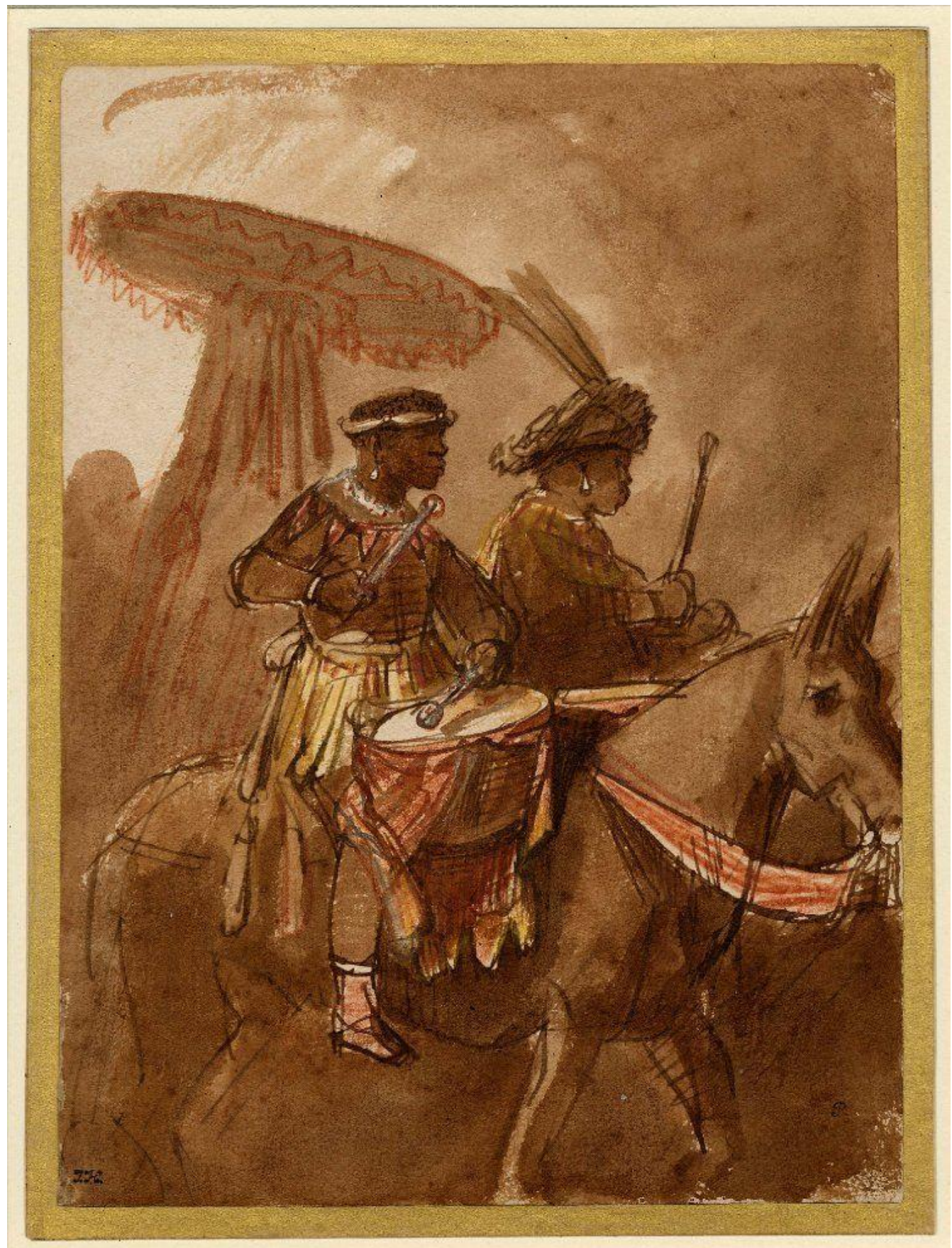

Figure 4. 


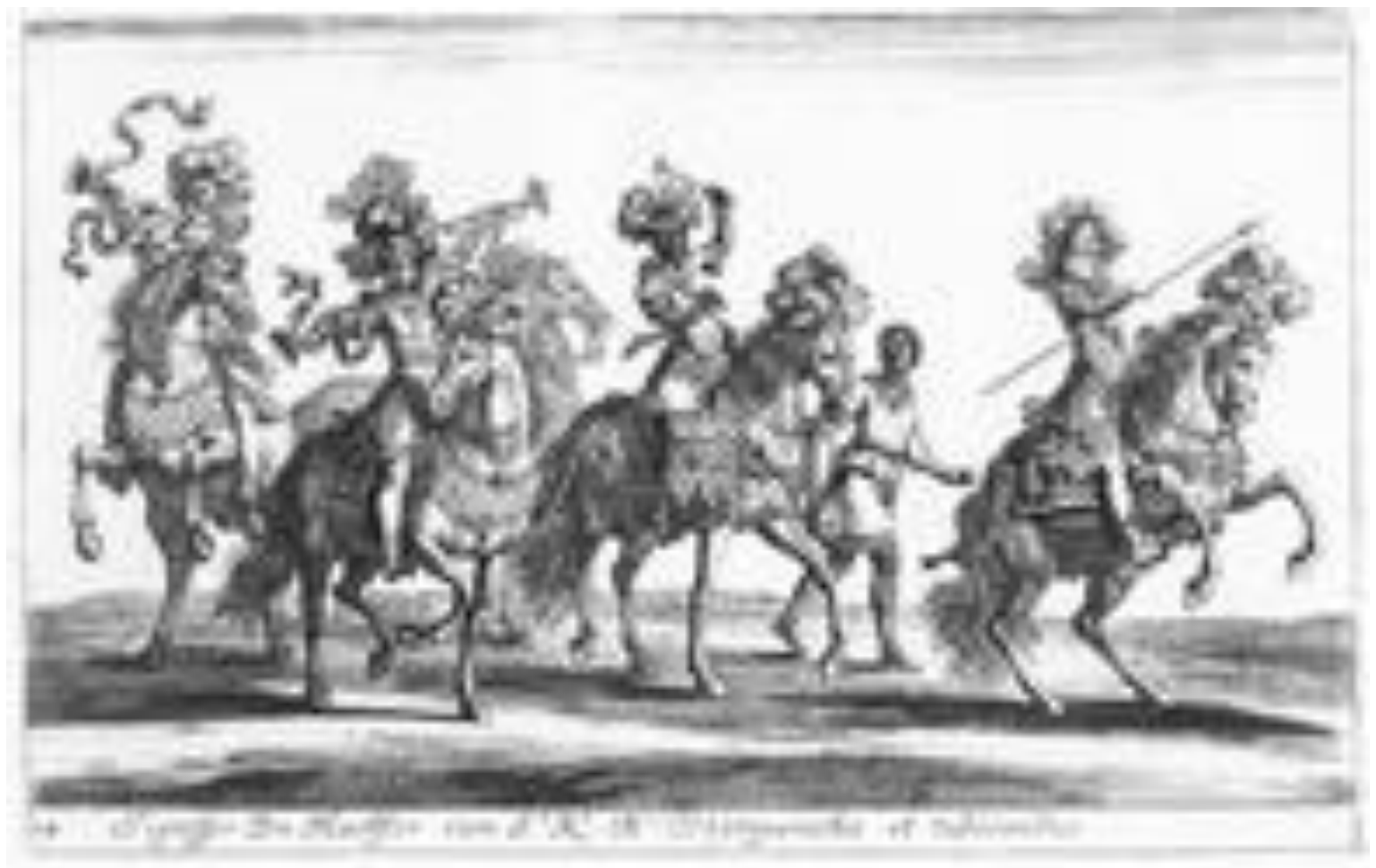

Figure 5. 


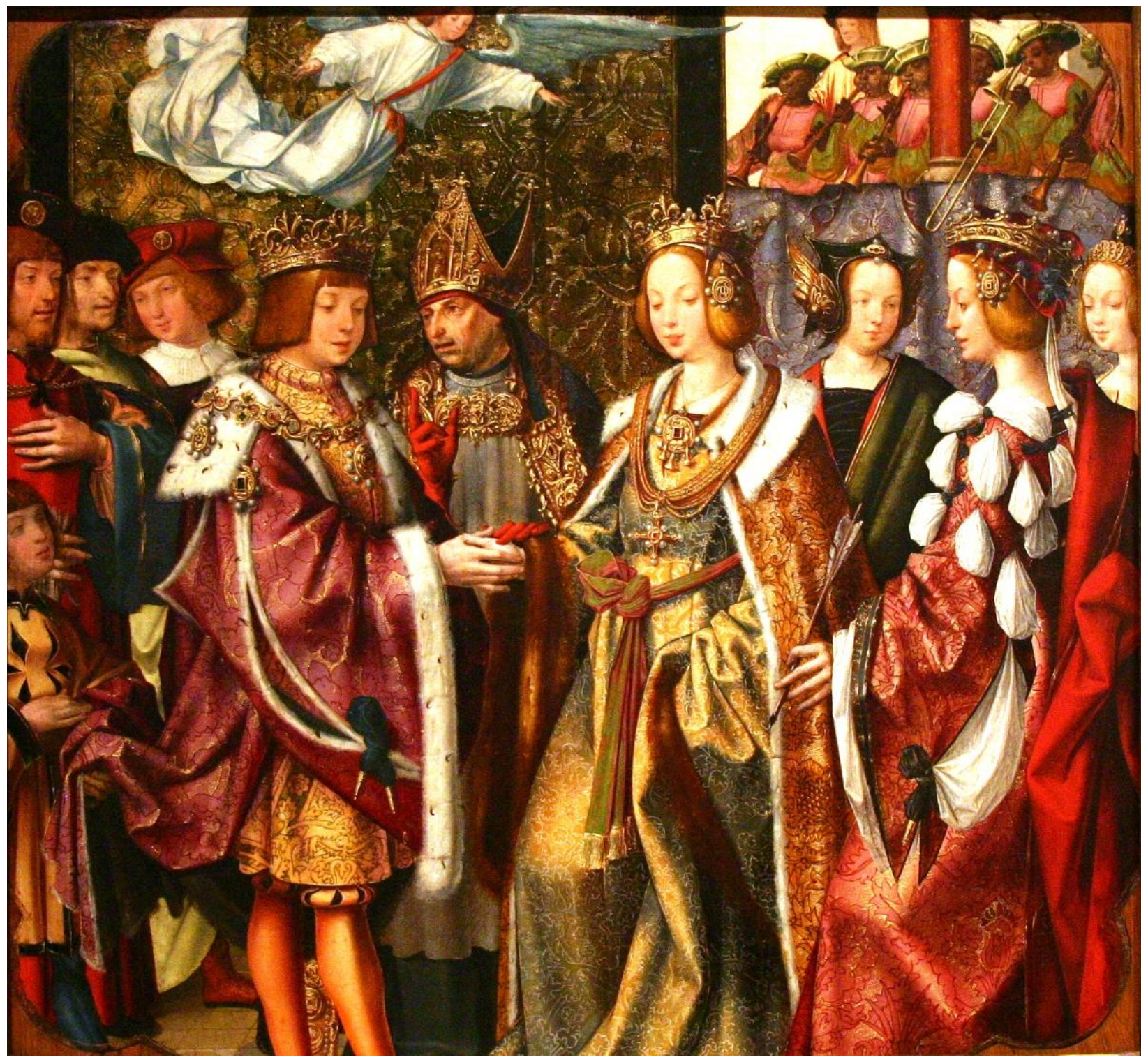

Figure 6. 


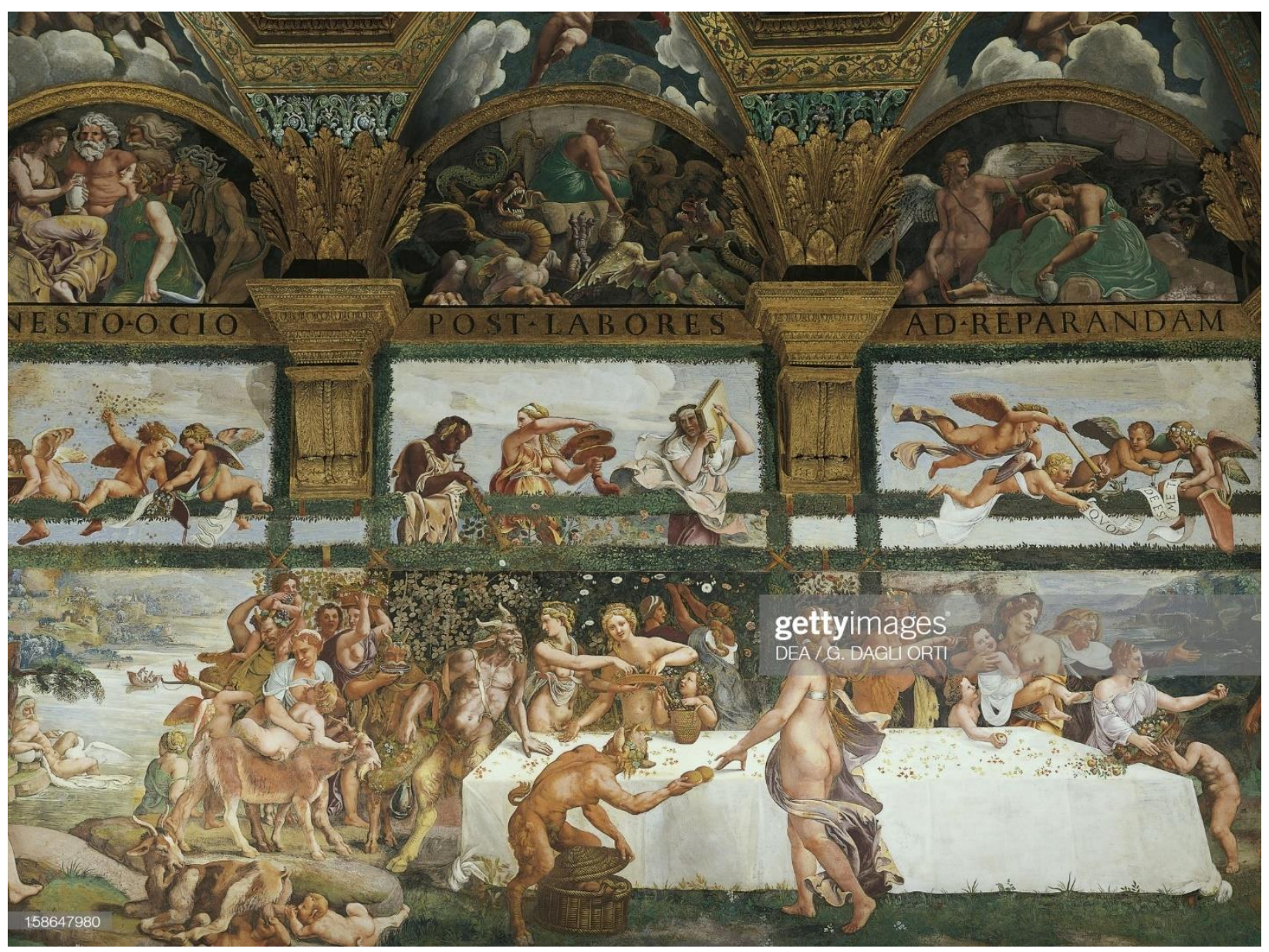

Figure 7. 


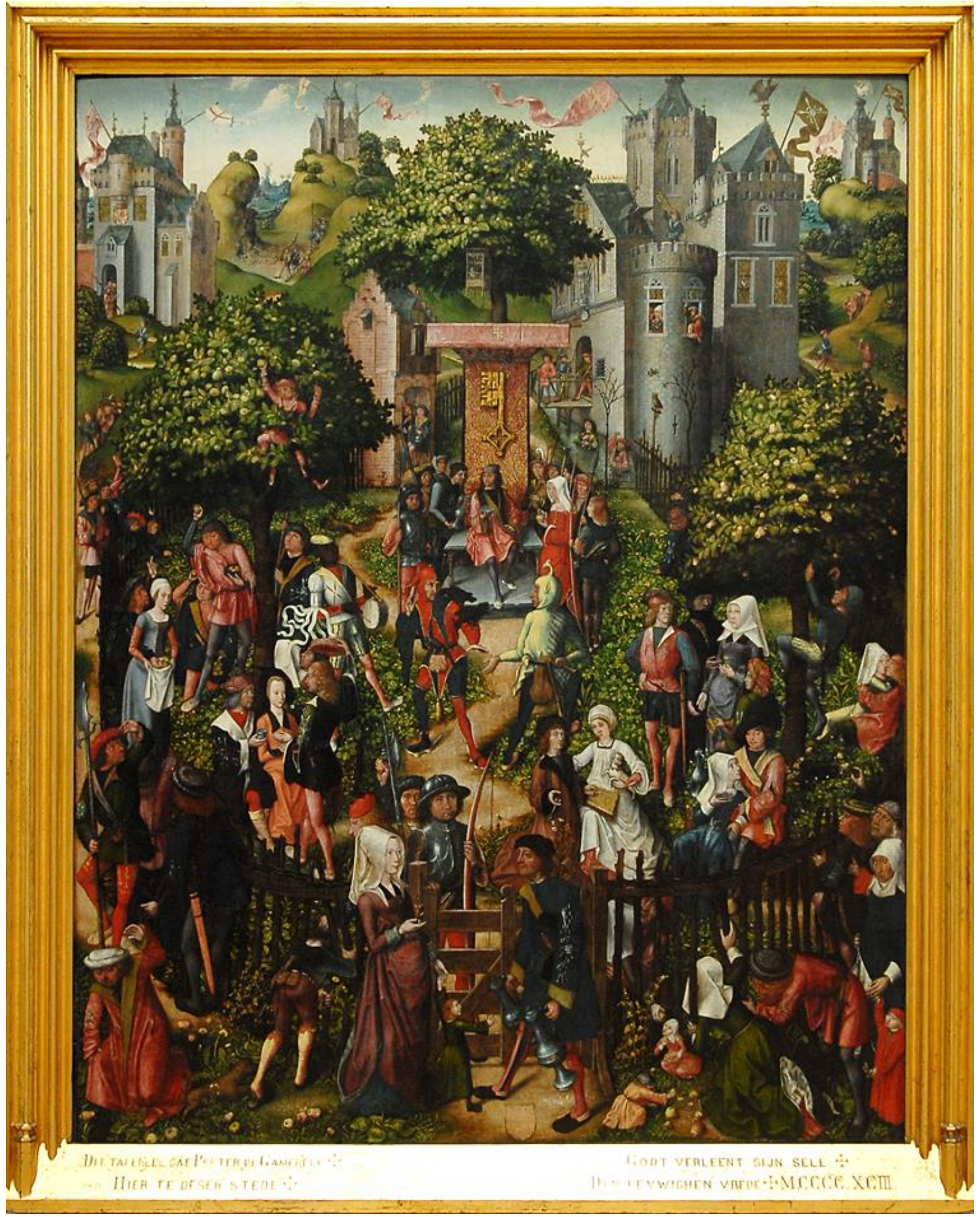

Figure 8. 